\title{
Moses' "Revelation" on Mount Horeb as a Near-Death Experience
}

\author{
Dov Steinmetz, M.D.
}

Central Emek Hospital, Afula, Israel

ABSTRACT: Moses, the leader and lawgiver to the people of Israel, went through a metamorphosis during his stay in the Sinai Desert, which can be explained as a near-death or near-death-like experience. Moses saw and heard God in the burning bush and yet survived. Following his revelation, he reached a higher level of consciousness, which enabled personality changes to occur. From being a simple shepherd of his father-in-law's flock, he turned into a prophet and charismatic leader of his people.

Humanity has always been fascinated by the Biblical stories and the many "supernatural" phenomena described therein. Through the ages, attempts have been made to explain Biblical phenomena on scientific grounds. For example, the ten plagues (Exodus 7-12) have been explained in terms of natural scourges that occur seasonally in Egypt. The first plague, water turning to blood, has been explained as pollution with fungi, plants, and insects, which is known to turn the waters of the Nile blood-red from time to time (Mazar, 1959). Darkness, the ninth plague, has been explained as a terrible sand and dust storm brought in by the Khamsin, the hot desert wind of the Egyptian spring (Wright, 1970).

Dov Steinmetz, M.D., is with the Department of Family Medicine at Central Emek Hospital in Afula, Israel. This article was written while he was a Visiting Professor at the Ohio State University. Reprint requests should be addressed to Dr. Steinmetz at Kibbutz Yagur 30065, Israel. 
Albert DeGrazia (1983) tried to find a general explanation for all the mysteries connected with the story of Moses and the Exodus from Egypt. He hypothesized that the Exodus occurred in an extraordinary setting in which major cosmic, atmospheric, and geological events took place, including a rare combination of a comet approaching the surface of the earth, meteorites, celestial dust and chemicals, and earthquakes. For example, DeGrazia explained the verse "And the Lord went before them by day in a pillar of cloud to lead them along the way, and by night in a pillar of fire to give them light, that they might travel by day and by night" (Exodus 13:22) as a comet that was seen as a dust cloud during the day and a fire ball during darkness.

In this paper I suggest that Moses' "revelation" on Mount Horeb has characteristics of a near-death or near-death-like experience, which produced in Moses a profound personality transformation and a sense of a divine mission.

\section{Moses' Revelation and Transformation}

While grazing his flocks near Mount Horeb (now known as Mount Sinai), Moses one day chanced upon a burning bush:

And the angel of the Lord appeared to him in a flame of fire out of the midst of a bush: and he looked, and lo, the bush was burning, yet it was not consumed. And Moses said, "I will turn aside and see this great sight, why the bush is not burnt." When the Lord saw that he turned aside to see, God called to him out of the bush, "Moses, Moses!" And he said, "Here am I." Then he said, "Do not come near; put off your shoes from your feet, for the place on which you are standing is holy ground." (Exodus $3: 2-5$ )

God then told Moses that He had seen and heard the suffering and crying of the people of Israel who were in Egypt. In the vision God bade Moses redeem Israel from Egypt and bring them to the "Promised Land."

Moses was a leader, prophet, and lawgiver, commissioned to take the Israelites out of Egypt. It is reasonable to assume that during his long stay in the desert Moses reached a higher level of consciousness that Stanley Dean (1975) called ultraconsciousness: "The ultraconscious summit is a genuine metamorphosis of consciousness which has been experienced by certain sages, prophets, leaders and men of genius through the ages" (p. 12). 


\section{Comparison with Near-Death Experiences}

I suggest that Moses' transformation could have been triggered by a near-death or near-death-like experience. Kenneth Ring (1984) pointed out many characteristics common to the near-death experience (NDE) and ultraconsciousness. Those pertinent to Moses' story include an encounter with the light, a life review, personality changes, and a sense of mission.

\section{The Light}

Raymond Moody, one of the pioneers who studied and described the NDE, wrote: "What is perhaps the most incredible common element in the accounts I have studied, and is certainly the element which has the most profound effect upon the individual, is the encounter with a very bright light" (1975, p. 55). Dean wrote of the characteristics of ultraconsciousness: "The onset is ushered in by awareness of dazzling light that floods the brain and fills the mind" $(1975$, p. 10). Moses saw the fire and was startled at first because the bush went on burning "yet it was not consumed."

Henry Abramovitch translated into English an NDE originally written in Hebrew. The experiencer wrote that he saw the light and became the light, but "The light was itself myriads of flames and auras, tints and hues" (1988, p. 178). As a traditional Jew, the experiencer must have been aware of the fact that both words he used, "light" and "flames," symbolically represent God (Fenske, 1990). In view of the Biblical insistence that no one can see God and live, it is reasonable to regard Moses' having seen God in the fire and yet survived it as a neardeath experience.

\section{Life Review}

NDErs often report that in their experiences they went through a review of their lives. The review or the memories may come all at once or in chronological order. Myer Pearlman described a similar life review of Moses:

In a flash, everything must have fallen in place in Moses' mind. There had clearly been a specific purpose to the apparently chance and random events in his past. ... He had turned them over in his mind, rather like a rotation of a mental kaleidoscope, and in an instant, the revelation at Mount Horeb had produced a clear design, full of mean- 
ing. . . His entire life up to this moment had been a preparation for his role of destiny. (1974, p. 49)

\section{Personality Changes}

In the ultraconscious state, there is an intellectual illumination and a charismatic change in personality. Moody (1975) and even more so Ring (1984) described the personal and value transformations that occur following NDEs. As a result, near-death experiencers report that they reached a much higher level of spirituality.

Following the "revelation" at Mount Horeb, Moses reached a very high spiritual level; he became a charismatic leader and the moral authority to his people. The transformation could easily be recognized, simply by watching Moses's face when he came down from the mountain: "And when Aaron and all the people of Israel saw Moses, behold, the skin of his face shone" (Exodus 34:30).

\section{Sense of Mission}

Dean described a sense of mission reported especially after reaching the ultraconscious summit: "The ultraconscious revelation is so moving and profound that the individual can not contain it within himself, but is moved to share it with all fellow men" (1975, p. 11). Ring concluded, in his summary of the value changes induced by NDEs: "Most NDErs also state that they live afterward with a heightened sense of spiritual purpose" (1984, p. 141).

Moses accepted the mission for which God had designated him:

And Moses told Aaron all the words of the Lord with which he had sent him, and all the signs which he had charged him to do. Then Moses and Aaron went and gathered together all the elders of the people of Israel. And Aaron spoke all the words which the Lord had spoken to Moses, and did the signs in the sight of the people. (Exodus 4:28-30)

\section{Conclusion}

Moses, despite having an unusual life story, had been an ordinary man from birth up to the time he escaped to the desert to become a shepherd of his father-in-law Jethro's flock. He then reached the ultra- 
conscious summit on Mount Horeb, and had an NDE or an NDE-like experience in the Sinai Desert. After this "revelation" on Mount Horeb, Moses' personality changed and he transformed into a charismatic leader and the lawgiver to the people of Israel.

\section{References}

Abramovitch, H. (1988). An Israeli account of a near-death experience: A case study of cultural dissonance. Journal of Near-Death Studies, 6, 175-184.

Dean, S. R. (1975). Metapsychiatry: The confluence of psychiatry and mysticism. In S. R. Dean (Ed.), Psychiatry and mysticism. Chicago, IL: Nelson-Hall.

DeGrazia, A. (1983). God's fire: Moses and the management of Exodus. Princeton, NJ: Metron.

Fenske, E. W. (1990). The near-death experience: An ancient truth, a modern mystery. Journal of Near-Death Studies, 8, 129-149.

Mazar, R. (Ed.). (1959). Views of the Biblical world. I: The law. Chicago, IL: Jordan.

Moody, R. A. (1975). Life after life. Covington, GA: Mockingbird.

Pearlman, M. (1974). Moses: Where it all began. New York, NY: Abelard-Schuman.

Ring, K. (1984). Heading toward omega: In search of the meaning of the near-death experience. New York, NY: William Morrow.

Wright, E. G. (1970). Biblical archaeology. Philadelphia, PA: Westminster. 